\title{
FORSAKING EQUALITY: EXAMINE INDONESIA'S STATE RESPONSIBILITY ON POLYGAMY TO THE MARRIAGE RIGHTS IN CEDAW ${ }^{\Omega}$
}

\author{
Nurhidayatuloh, ${ }^{1}$ Febrian, ${ }^{1}$ Achmad Romsan, ${ }^{1}$ Annalisa Yahanan, ${ }^{1}$ \\ Martinus Sardi, ${ }^{2}$ and Fatimatuz Zuhro ${ }^{3}$ \\ ${ }^{1}$ Faculty of Law, Universitas Sriwijaya, Palembang - Indonesia \\ E-mail: nurhidayatuloh@fh.unsri.ac.id \\ ${ }^{2}$ Faculty of Law, Universitas Muhammadiyah Yogyakarta \\ ${ }^{3}$ Faculty of Law and Sharia, Universitas Islam Negeri Sunan Kalijaga
}

\begin{abstract}
Human rights violation (HRV) occurs when a state including its organs commits HRV to individual within its jurisdiction. International Law has formulated a wide range of human rights law, especially the CEDAW which has been ratified through Law No. 7 of 1984. However, the law has not been applied properly. This article aims to examine HRV committed by a state which caused inability or unwilling to amend polygamy Law. Based on normative research, analysis to Article 2(f) of the Convention applies a viewpoint equality and state responsibility theories. Through this method, international conventions will be opposed to national provisions, Polygamy regulation. It is found that Indonesia through Polygamy regulation performs discrimination against woman's rights. It can be stated that Marriage Law treats men and women unequal. It concludes that, as a state, Indonesia should responsible for HRV because the main problem of inequality is discrimination rooted from Polygamy regulation.
\end{abstract}

Keywords: equality, human rights violation, non-discrimination, polygamy, state responsibility

\begin{abstract}
Abstrak
Pelanggaran hak asasi manusia (HAM) terjadi ketika negara termasuk organ di dalamnya melakukan pelanggaran HAM terhadap individu dalam wilayah yurisdiksinya. Hukum internasional telah mengatur ketentuan HAM yang mengikat bagi Indonesia seperti CEDAW dan telah diratifikasi dengan dasar hukum Undang-Undang Nomor 7 Tahun 1984. Namun demikian dalam kenyataannya aturan ini tidak berjalan sebagaimana mestinya. Artikel ini bertujuan untuk membahas pelanggaran HAM yang dilakukan negara atas dasar ketidakmampuan atau ketidakmauan untuk mengubah Pasal 3 Undang-Undang Perkawinan (UUP). Berdasarkan penelitian normatif yang dilakukan, analisis terhadap Pasal 2(f) CEDAW menggunakan pisau analisis teori kesetaraan dan tanggung jawab negara. Melalui metode ini, kovenan internasional dihadapkan dengan peraturan perundang-undangan di Indonesia khususnya UUP. Hasil penelitian ini menyatakan bahwa Indonesia melalui UUP tentang poligami telah melakukan diskriminasi terhadap hak perempuan. Dapat dikatakan UUP tidak memposisikan perempuan dan lakilaki secara setara. Dapat disimpulkan bahwa, sebagai negara, Indonesia harus bertanggung jawab terhadap pelanggaan HAM karena memperlakukan ketidaksetaraan adalah diskriminasi.
\end{abstract}

Kata kunci: kesetaraan, pelanggaran hak asasi manusia, non-diskriminasi, poligami, tanggung jawab negara

\section{Introduction}

Polygamy in Indonesia is stipulated in the Law Number 1 Year 1974 on Marriage (Marriage Law) ${ }^{1}$ and government rules following the law. Article 3(2) Marriage Law articulates that "a

$\Omega \quad$ The article is the result of research according to the Dean Decree of Faculty of Law, Universitas Sriwijaya Number: 10/UN9.1.2/KP/2017.

1 The Marriage Law, Article 3(2). husband is possible to marry more than a wife" and it means that polygamy is permitted for a man, but polyandry is forbidden to a woman. This article embeds polygamy when it is confronted with the principle of equality in the Convention on the Elimination of All Forms of Discrimination against Women (CEDAW). Whereas, the principle of state responsibility descri- 
bes that nondiscrimination among people should be guaranteed by Indonesia as a consequence of CEDAW ratification. The paper will investigate further about Article 3(2) of Marriage Law confronted with those principles formulated in the UDHR and CEDAW Article 16.

Polygamy is a crucial issue for its relation to religion, adat law and human rights law. Moreover, this topic is also crucial because most Indonesian citizens are Muslims. Similarly, in term of the issue of discrimination based on sexual orientation, it cannot be avoided by church authority ${ }^{2}$ and Muslim concern. However, although the marriage law in Indonesia is not an Islamic law, the substance comes from the Koran and sunnah.

Discrimination often takes place in a number of areas. Such as, society, politics, economy, and leadership, not only physical violence but also psychological one. ${ }^{3}$ In the family scope, women must work only as a housewife since a long time, for instance take care of their husband, children, and households. These sorts of things are certainly not in line with the values that human beings have been created equally. They have virtues (فضل) as it is documented in the Chapter 3 of the Koran (Sura alNisa') and were created to complete each other. However, women also have a role to be respected for by men. The roles of women in the family, social, economic, legal, and political aspects must be equal. This is the philosophical basis of why women rights and freedoms need to be enforced under human rights law.

Since 1945, international law has developed a large framework of human rights protection from state intervention. In addition, human rights substance in the United Nations Charter become the main purpose of the Universal Declaration of Human Rights (UDHR) and more specific rights related to women are stipulated in the CEDAW. in CEDAW, most of the articles

2 Dominic Mcgoldrick, "The Development and Status of Sexual Orientation Discrimination under International Human Rights Law", Human Rights Law Review, Vol. 16 No. 4, December 2016, p. 613-668.

3 Hanafi Arief, "Legal Protection Against Women Victims by The Indonesian Domestic Violence Act 23 , 2004", Sriwijaya Law Review, Vol. 1. No. 1 January 2017, p. 88 97. started with the words "states parties shall take...". It indicates that the CEDAW requires state action to protect women rights. Therefore, state has obligation to take all responsibilities, namely the obligation to fulfil, to protect, and respect for the individuals. Furthermore, Article 10 explicitly states "to ensure through competent national tribunals" with the purpose of women protection from discrimination.

On the one hand, in terms of state's obligation whilst a state does not perform a fulfillment, protection, and respect to human rights, the state has committed human rights violation. Similarly, when a state protect human rights by making irrelevant regulations, the state has committed human rights violations.

The author read some articles related to polygamy entitled as the implementation of polygamy. Some given articles only discussed a role and function of judges towards an application of polygamy to a court, especially in the subject of how judges take a decision related to polygamy requested by a husband and how to consider it. ${ }^{4}$ There are enormous works which discuss polygamy with a viewpoint of Islamic law and fiqh. For example articles written by Mohammad Fateh which discuss polygamy in the context of Islamic law and its application in Indonesia ${ }^{5}$ as well as Abdul Mustaqim who asserts that according to Sahrur's view, the nature of marriage is monogamy. However, another view from Abdul Mustaqim depicts that polygamy is possible to perform only as a solution to social problems. ${ }^{6}$ Hence, the novelty of this article which has never been examined in those article is polygamy seen from the view-point of state responsibility as a part of human rights violation.

Human rights violation is a unique phenomenon because the concept of human rights

\footnotetext{
Sanyoto, "Implementasi Poligami Antinomi Antara Individual Rights Dan Social Rights," Jurnal Dinamika Hukum, Vol. 8 No. 1 , January 2008, p. 51-55.

5 Ahmad Mustofa and Khoirul Fata, "Menyoal Kontekstualisasi Hukum Islam Tentang Poligami", Jurnal Al-Ulum, Vol. 13 No. 2, December 2013, p. 415-434.

6 Abdul Mustaqim, "Pemikiran Fikih Kontemporer Muhamad Syahrur Tentang Poligami Dan Jilbab", Al-Manahij, Vol. 5 No. 1, January 2011, p. 67-80.
} 
violation have been established especially last two decades to a new direction. The new notion began from a mission of the International Centre for Transitional Justice (ICTJ) that is "ICTJ assist societies to confront gross violation of human rights to promote accountability, pursue truth, provide reparations and build trustworthy institution". The aim of the mission is responsibility of a government to human rights violation. ${ }^{7}$ It is true that a classical concept of international law is only applied between states, but currently individual also has opportunity to defend against a state. ${ }^{8}$

It is inevitable that international convention takes a primary role in national law system with ratification. It argues that once Indonesia ratified international convention, it means that Indonesian government must follow the rule and add the international convention as applied law in Indonesia.

This article will discuss further polygamy law in Indonesia as a member of the CEDAW with the viewpoint of a state which is the only party able to violate human rights. Does Indonesia violate women rights? why polygamy regulation had been arranged in UUP?

\section{Research Methods}

This article applies statute approach as well as analytical method including juridical qualitative data. Statute approach is applied to examine the polygamy policy in Indonesia from the CEDAW. As a viewpoint, author applies the theory of equality in CEDAW expressed by Alda Facio and Martha I Morgan and state responsibility theory by Malcolm N. Shaw. Moreover, the principle of equality or CEDAW Principles of Equality ${ }^{9}$ specifically consists of the principle of non-discrimination and the principle of state

Hurst Hannum, "Reinvigorating Human Rights for the Twenty-First Century," Human Rights Law Review, Vol. 16 No. 3, September 2016, p. 1-43.

8 M Cherif Bassiouni, "International Recognition of Victims' Rights," Human Rights Law Review, Vol. 6 No. 2, January 2006, p. 203-279.

9 Alda Facio, and Martha I. Morgan, "Equity or Equality for Womern? Understanding CEDAW's Equality Principles," Alabama Law Review, Vol. 60 No. 5, September 2009, p. 2. responsibility ${ }^{10}$ and the theory of state responsibility depends on the following factors: first, the existence of an international legal obligations; second, the existence of a law or omission that violates the international legal obligations arising the responsibility of the state; and third, any damage or loss as a result of an unlawful act or negligent. ${ }^{11}$

\section{Discussion}

\section{Islamic Law and Polygamy}

A term either wife or husband marrying to more than one person in the Indonesian Dictionary (KBBI) is described as follows: first, polyandry is the marriage system allowing a woman has more than one husband at the same time; second, polygamy is a system in which one party marries several wives or husbands at the same time; third, polygynous constitute married system permitting a man has several wives at the same time. Some scholars, such as, Musdah Mulia mentions that polygamy is the bond of marriage in which one party (husband) marrying multiple (more than one) wives at the same time. ${ }^{12}$

In Islam, polygamy is depicted at Surah an-Nisa' (3):

"And if you fear that you shall not be able to deal justly with the orphan girls, then marry (other) women of your choice, two or three or four but if you fear that you shall not be able to deal justly (with them), then only one or (slaves) that your right hands possess. That is nearer to prevent you from doing injustice."

Words, such as مثنى meant two people (women), تلث meant three females and ربع meant four women. Prophet Muhammad immediately prohibited to collect more than four wives after this verse, so he ordered all of his friends (sahabat) who had several wives to be divorced till remained four. In a hadith narrated by Abu Da-

\footnotetext{
Ibid.

11 Malcolm N Shaw, 2008, International Law, 6th edition, Cambridge: Cambridge University Press, p. 778.

12 Siti Musdah Mulia, 2004, Islam Menggugat Poligami, Jakarta: PT Gramedia Pustaka Utama, p. 43-44.
} 
wud mentioned that 13 This مسك أربعا وفارق سائرهن Thad hadith from Ibn 'Umar when Ghailan ibn Salamah ats-Tsaqafi whose ten wives. ${ }^{14}$ After he became Muslim, he divorce six of all his wives.

According to the verse, at least there are two prominent notions discussing polygamy. The first view is those who support polygamy and the second is those who forbid polygamy. Most scholars (jumhur) who support polygamy are dominated by a view that polygamy is only limited to four wives, even though also some assert that polygamy can be performed up to nine woman and nineteen women such as Zahiri School and Khowarij respectively. ${ }^{15}$ Supporting jumhur, Wahbah al-Zuahaily argues that polygamy can be performed for only four wives. He gives a reason with a comparison "week and month". If a month has four weeks and every week one wife, it is sufficient for the husband to give affection and love four wives in a month. ${ }^{16}$

\section{Polygamy in Indonesian Context: Law and Practice}

The legislation of polygamy is an issue which must be overcome by most Islamic countries. On this problem, Islamic countries indeed experience a various way to respond this matter which will be described in the following table.

Table 1. Polygamy legislation in some Islamic countries $^{17}$

\begin{tabular}{ll}
\hline Countries & Polygamy legislations \\
\hline Brunei Darussalam & Permitted \\
Malaysia & Permitted \\
Morocco & Permitted \\
Syria & Judge decision \\
Tunis & Forbidden \\
\hline Source: Collected independently
\end{tabular}

The figure depicts polygamy laws in several Islamic countries. Malaysia, Brunei Darussalam and Morocco permit polygamy in their law, while Syria depends on judge's verdicts. There is no strict rule to permit or forbid polygamy in

\footnotetext{
13 Sunan Abu Dawud: Kitab An-Nikah, Bab "Mā Jā-a Firrajuli Yuslimu Wa 'indahu 'Asyru Niswah "Juz 3, Hadits Number. 901.

14 Ibid.

15 Ahmad Mustofa and Khoirul Fata, Op.Cit., p. 415-434.

16 Atik Wartini, "Poligami: Dari Fiqh Hingga Perundang-Undangan." Hunafa: Jurnal Studia Islamika, Vol. 10 No. 2, December 2013, p. 237-268.

17 Ibid.
}

the state. However, it can be acknowledged that in Tunis polygamy absolutely forbidden. The reason why polygamy is not allowed in Tunis is that polygamy cannot be performed in civilized nations. ${ }^{18}$

In Indonesia, the issue of marriage is regulated in an act. Moreover, it is also expressed to the Government Regulation (PP) Number 9 Year 1975 on the Implementation of the Law Number 1 Year 1974 and Presidential Instruction (Inpres) Number 1 Year 1991 on the Compilation of Islamic Law (KHI). For Public Civil Servants (PNS), It is tied up by Government Regulation Number 10 Year 1983 on the Licensed Marriage and Divorce and Government Regulation Number 45 Year 1990 on the Amendment of Government Regulation No. 10 Year 1983.

Article 3 of the Marriage Law states "The basic principles of marriage, a marriage of a man should only have one wife. A woman should only have one husband." (2) The court may grant to a husband to marry more than one when it is permitted by both parties." It means that the principle of marriage is "opened-monogamy." The word "open" has a further consequence that only for which capable to have more than a wife, but not for woman. The article is applied only to a woman concerning to the principle of monogamy, allowed to have a husband. On the contrary, the court may grant a license to husband to marry more than one person when it is desired by the parties. ${ }^{19}$

The following article, Article 4(2), declares that the court may decide a husband to marry more than one wife with certain conditions, namely: first, a wife cannot perform her duties; second, a wife got a disability or illness which is highly unlikely to be cured; third, a wife is unable to give birth. Somehow, there is a problem whether the conditions are alternative or cumulative. In fact, if the judges meet one of the conditions, it will be considered that it has been achieved. Thus, commonly the three

\footnotetext{
Ibid.

Nurhidayatuloh, 2008, Pertimbangan Hakim Dalam Kasus Poligami (Studi Putusan Pengadilan Agama DIY Tentang Poligami Tahun 2006), Yogyakarta: Sunan Kalijaga State Islamic University, p. 114.
} 
reasons constitute alternative requirements. ${ }^{20}$ In addition, Article 4(2) of the Marriage Law stipulates additional requirements, namely: first, wife's approval; second, assurance from husband to ensure needs of wives and children; and third, assurance from husband that he is just to his wives and children.

Not only alternative requirements but also cumulative stipulations must be fulfilled. Firstly, permission from the court, then a husband shall apply officially to the court; secondly, it must be attached by consent of wife(s); thirdly, the husband should indicate ability to guarantee needs of his wives and children. Finally, ability for just to his wives.

In practice, the aim of polygamy indeed to solve a social problem, such as economy, education and so forth. However, polygamy often causes inharmonic relation between husband and wife or between wives. Whereas, the main purpose of marriage is to perform a sakinah (tranquility), mawaddah (love), and rahmah (mercy) relation. For example in Langsa city, Aceh, most polygamy families are scarcely to live without quarrel and conflict. Even though it is also possible polygamy cases are pleasant yet it is rare. ${ }^{21}$ In addition, based on research there is a dominant symptom of depression especially women. The dominant symptom is emotional which is expressed by feeling angry, disappointed, sensitive, inferior and suffering heartache. ${ }^{22}$

Another case is "illegal" Polygamy, married without being registered by Office of Religious Affairs, as occurred in Pamekasan, a district in East Java. It is asserted that Islamic law is more important than positive law. ${ }^{23}$ Moreover, in Probolinggo a number of kyai, Islamic

20 Muhammad Ansor, "Berbagi Suami Atas Nama Tuhan: Pengalaman Keseharian Perempuan Dipoligami Di Langsa", Ijtihad, Jurnal Wacana Hukum Islam Dan Kemanusiaan, Vol. 14 No. 1, June 2014, p. 41-63.

21 Wilda Triana Sutandi, "Gambaran Simtom Depresi Pada Istri Yang Dipoligami", Neotic Psychology, Vol. 1 No. 2 , January 2011, p. 102-109.

22 Abd. Warits and Abd. Wahed, "Praktik Poligami Di Bawah Tangan Di Desa Laden Kabupaten Pamekasan", AL-Ahkam, Vol. 9 No. 2, December 2014, p. 223-259.

23 Ita Musarrofa, 'Poligami: Antara Legalitas Formal Dan Legalitas Budaya (Studi Kasus Praktik Poligami Kyai Pesantren Di Probolinggo Jawa Timur', Al-Mawarid, Vol. 14 No. 1, 2005, p. 198-211. boarding house leaders, marry more than one woman. At least, there are two possibilities for kyai to perform polygamy, namely legal polygamy and sirri polygamy. Polygamy which is registered by the Office of Religious Affairs is known as legal polygamy while polygamy which is performed without permission by the Religious Court is so-called by sirri polygamy. Both practices live in Probolinggo. ${ }^{24}$ Consequently, according to these cases, polygamy is most likely tends to discriminate women.

\section{International Law and State Responsibility}

Discussing polygamy through international agreement leads to a new awareness that human rights subject is also international law domain (outward looking). ${ }^{25}$ In fact, human rights emerge from universal declaration and has been strengthened by international agreements.

There are two engagement principles on international law namely the principle of pacta sunt servanda and the principle of pacta terties nec nocent nec prosunt. The former principle is a result of customary law $^{26}$ then it is formulated to Article 26 of the Vienna Convention, every treaty is binding upon between parties and must be performed in good faith. Whereas the latter is the principle of pacta terties nec nocent nec prosunt. This principle contains basic principle that a convention is only binding to the parties. The Vienna Convention addresses the principle as "general rule". It means that the principle not only causes rights and obligations for the third parties but also implies that the convention does not bind for the third parties without their consent. ${ }^{27}$ This is an impact the principle of state sovereignty formulated in the Article 34 of the Vienna Convention on the Law of Treaties.

24 Nurhidayatuloh, "Dilema Pengujian Undang-Undang Ratifikasi Oleh Mahkamah Konstitusi Dalam Konteks Ketetanegaraan Rl", Jurnal Konstitusi, Vol. 9 No. 1, March 2012, p. 114.

25 Knut D. Asplund, Et Al., ed., 2008, Hukum Hak Asasi Manusia, Yogyakarta: PUSHAM UII, p. 3.

26 Justice J.S. Verma, "Human Rights Redefined: The New Universe of Human Rights", Journal of the NHRC, Vol. 1 No. 12002 , p. 1-17.

27 Cahya Wulandari and Indung Wijayanto, "Gender-Based Restorative Justice for Victims of Violence Against Women", Jurnal Dinamika Hukum, Vol. 15 No. 1, January 2015, p. 82-88. 
It asserts that a treaty does not create either obligations or rights for third party to a convention without its consent. However, even though the convention only ties up to the parties, in certain case, as defined in Article 38 of the Convention known as customary international law, as the consequence, then, third parties shall be bound.

In international law, state is an important entity which holds rights and obligations. The Montevideo Convention 1933 on the Rights and Duties of States stipulates that a state must has a fixed population, a specific region, government, and sovereignty. Some people believe that due to sovereignty, interference is not allowed. However, although the state has sovereignty, it must be guaranteed that the state avoid abuse of power to their people and must respect other countries. ${ }^{28}$ Thus, provisions about state responsibility must be related to state's jurisdiction. In addition, state responsibility includes commission or commission state's acts. ${ }^{29}$

Some scholars acknowledge that states responsibility is a fundamental principle, but they also know that the rule of state responsibility is still developed. Malcolm N. Shaw asserts that several characteristics of state responsibility depend on the following factors: first, the existence of an international legal obligations; second, the existence of an act or not violating the international legal obligations and rises responsibility of the state; and third, any damage or loss as a result of an unlawful act or negligent. $^{30}$

In Indonesia, some concerns regarding to state responsibility is associated with the question of who can ask the responsibility to the state. Then how a state violates individuals or citizens rights, and how a state responsible for human rights violations? For instance in case of polygamy in Indonesia. If problem of polygamy in the Marriage Law is a violation of international law then how the individuals ask respons-

28 Huala Adolf, 2002, Aspek-Aspek Negara Dalam Hukum Internasional, Jakarta: PT RajaGrafindo Persada, p. 225.

29 Ibid., p. 265.

30 Malcolm N. Shaw, op.cit., p. 781. ibility to Indonesia against such violations. Who has jurisdiction and who will decide it? Indonesian Constitutional Court may be the most appropriate institution to judge human rights violation because state can be a party against individual but the competence of the court is limited, for example examine the law to the 1945 Constitution.

The provisions in the Responsibility of States for Internationally Wrongful Acts has been set and categorized as the state action in detail. Some of its provisions, Articles 1 and 4 (1), stipulates that any of state action can be categorized as Internationally Wrongful Acts and arises responsibility includes acts committed by the states organs, for example legislative, executive and judiciary organs.

\section{Women Rights in the Scope of International and Indonesia}

In Indonesia, according to Article 77 and 72 the Law Number 39 Year 1999 on Human Rights (Human Rights Act) state has duties and responsibilities. The duties and responsibilities include respect, protection, enforcement, and promotion of human rights. ${ }^{31}$ Women rights become an important concern in this law. Verma said that human rights are indivisible, inter dependent and inter related, and inseparable from human development. ${ }^{32}$ Human are created with natural dignity and equal rights. It means that no one is superior to each other. They have their respective roles to be respected not only in the realm of family, social, economic, legal but also in the political field should be positioned equally. It seems that Indonesian government has not provided a sufficient space for women in certain laws and enabled Indonesia to violate women rights and gender-based inequality. ${ }^{33}$

31 Eko Hidayat, "Perlindungan Hak Asasi Manusia Dalam Negara Hukum Indonesia”, JURNAL ASAS, Vol. 8. No. 2 July 2016, p. 81.

32 Joni Efraim Liunima, "Progresive Law Enforcement Towards Human Rights Violation In Kupang City", Jurnal Dinamika Hukum, Vol. 16. No. 1 January 2016, p. 79-84.

33 Christanugra Philip, 'Tanggung Jawab Negara Terhadap Perlindungan Hak Asasi Manusia Menurut Hukum Internasional', Lex Administratum, Vol. 4. No. 2 February 2016, p. 33-39. 
The specific provision of human rights which concern women is the Convention on the Elimination of All Forms of Discrimination Against Women (CEDAW). Article 2 of CEDAW formulated as follows:

"States Parties condemn discrimination against women in all its forms, agree to pursue by all appropriate means and without delay a policy of eliminating discrimination against women and, to this end, undertake:... (b) to adopt appropriate legislative and other measures, including sanctions where appropriate, prohibiting all discrimination against women; (c) to establish legal protection of the rights of women on an equal basis with men and to ensure through competent national tribunals and other public institutions the effective protection of women against any act of discrimination... (f) to take all appropriate measures, including legislation, to modify or abolish existing laws, regulations, customs and practices which constitute discrimination against women; (g) to repeal all national penal provisions which constitute discrimination against women."

The article displays that realization of equality between men and women can be constituted through legal policies including legislation (legislative and other measures) in the form of legislation including sanctions.

In addition, Article 5 of CEDAW states that the delay of the implementation of human rights is also a violation and it is condemned by CEDAW (condemn discrimination against women). It is contained in the word "without delay a policy of eliminating discrimination against women." In other words, CEDAW did not want any delay in the implementation of the principle of equality for men and women. At the practical level, state must not arrange laws which tends to discriminate women. If the legislation has been legalized and against principle of the equality, the states are obligated to take actual steps to change or even abolish the laws.

Changing on legislation which contrasts to human rights is states responsibility. In this case, CEDAW as the only covenant that guarantees the women rights specifically and comprehensively can be used to measure the state's law. Indonesia has ratified the CEDAW through Law
Number 7 Year 1984 on the Ratification of the CEDAW with a reservation to Article 29 Paragraph (1) on the settlement of disputes concerning the interpretation or application of the Convention resolved through the International Court of Justice.

The implementation of a protection of human rights in Indonesia remains a problem, even though following Indonesian reform in 1998 there are improvements in this issue by ratifying a number of international covenants. ${ }^{34}$ Ratification means an obligation to follow the rules in the CEDAW. It means that Indonesia must be bound to implement in a good faith the convention. The state is not allowed to avoid its obligations with the reason of its national law. The constitution in Indonesia regulates human rights regarding to marriage. In Article $28 \mathrm{~B}$ of the 1945 Constitution declares that "everyone has the right to form a family and continue the descent through valid marriage." Then the specific chapter on human rights explored in the the Act Number 39 Year 1999 concerning Human Rights (Human Rights Act). Provisions regulating the issue of women in Human Rights Act set in the ninth section of Women Rights, Article 45 to 51. Women rights guarantee Human Rights Act in the realm of family is formulated under Article 10:

(1) Everyone has the right to form a family and continue the descent through valid marriage.

(2) A valid marriage can only take place on the free will of a husband and wi$\mathrm{fe}$, in accordance with the provisions of the legislation.

The article stated that marriage has been arranged in "provisions of the legislation." This refers to the Marriage Law and the some regulations below although Marriage Law exists before Human Rights Act. The issue is whether the provisions of polygamy still need to be set in the legislation or if there is a provision setting on it, the arrangements must change the patterns of social and cultural behaviors of men and women with a purpose to eliminate of all

\footnotetext{
34 Dominic Mcgoldrick, op.cit., p. 613-668.
} 
practices based on the inferiority or superiority of one sex.

\section{Polygamy in the Context of Non-Discrimina- tion and State Responsibility}

Citing the principle of responsive law which law serves human but not human serves law. It implies that law is not absolute body because law equality itself is the competence of the law to serve human to be a welfare. ${ }^{35} \mathrm{Hen}$ ce, law should not lead to discrimination.

The principle of non-discrimination completely contained in Article 1 of CEDAW by using the term of "all forms discrimination against women". The first aspect, discrimination is the presence of distinction or exclusion or restriction. Marriage Law stating that "the court may grant a license to a husband to marry more than a wife..." shows any distinction between men and women. In this case, it must be enforced the terms of distinction. The author finds some clear distinctions regulated in this law, namely; first, the act sets an article evoking a potential regulation that a man can marry more than one woman. Second, the act does not explicitly specify whether the woman may marry more than one man. In this act, it is only stated that "this act adheres to the principle of monogamy. Only if it is required by the parties, since the law and religion of the parties give the permission, a husband may have wives more than one." The sentence can be understood that at first the position between men and women are equal with the presence of the word "principle of monogamy," but the next word indicates an exception to the man with the words "husband may have wives more than one," but not vice versa. It means that for women go back to apply the principle of monogamy. Third, the provision of polygamy in this law does not provide a maximum limit to how many wives a man can marries to. The sentence in this law only mentions that "the court may grant a license to a husband to marry more than a wife..." without giving more explanation to the maximum amount.

35 Hanafi Arief, op.cit., p. 88-97.
The second aspect, the distinction, exclusion or restriction is not only oriented to the destination directly but also it has the effect or purpose. As mentioned above, the discriminating factor lies on the distinction set out in the legislation. The problem is whether this distinction has a nature of a direct destination or only as a result. The researcher finds that the distinction provided by Article 4 of Marriage Law is a direct goal for some reasons: First, The provision of polygamy is regulated directly and clearly by using the word "... wives more than one." Second, The reason becoming a consideration to allow polygamy only focuses on the wife. This can be seen in Article 4 (2) "the court only granted permission for a husband who would have more wives than one if: the wife cannot perform their duties as a wife; wife gets disability or incurable illness; wife cannot give birth to offspring." From these three conditions none of which focuses on the husband, it means that if there is one of the conditions are met, then the court may grant to polygamy.

The third aspect, discrimination could be either partial or total. Partial is a negation of certain aspects of the rights and total is a negation of a right totally. In Marriage Law, the rights and the position of wife and husband are equal. It is regulated in Article 31 of the Marriage Law, which states "the rights and positions of the wife are equal to the rights and status of the husband in a domestic matter and living together in a community. Each party has the rights to take a legal action. "However, in the case of polygamy, they do not have equal rights. This is proven by the distinctions and exclusions for husbands to marry more than one wife not vice versa. The discrimination on these three aspects is partial, that is, discrimination is only found in certain aspects of the marriage, that is, the aspects of polygamy. However, even if only in a partial matter, this could be categorized as discrimination.

The fourth aspect, the level of discrimination is on the recognition, enjoyment or exercise. Discrimination formulated in the provisions of polygamy is at the level of recognition since this discrimination occurred at the time of the 
making legislation that addresses women rights. According to The Making of Law 2011, Article 1 (3) an institutions that create acts, in Indonesia, are the House of Representative (DPR). Based on its hierarchy it is known that the law of polygamy in the Marriage Law is set in third place below the 1945 Constitution and TAP MPR. The practical regulations of Marriage Law, namely, Government Regulation (PP) Number 9 of 1975 on the Implementation of the Law Number 1 of 1974 on Marriage that also set about polygamy yet the level is lower than the act.

Indonesia should perform of good faith by changing the laws in line with the CEDAW principles of non-discrimination. ${ }^{36}$ Good faith is not only made by making drafts only proposed to the DPR. This is in accordance with the Article 5 of CEDAW which states "the States Parties shall take all appropriate measures: (a) to change the pattern of social and cultural behaviour of men and women... which is based on the inferiority or superiority of one sex." When the legislation made by the state did not express any principle of equality, the state is obliged to take concrete steps to change or even abolish the law. Therefore, it is necessary to change the rules of polygamy which tends to discriminate women.

The fifth aspect, CEDAW prohibits discrimination in all areas including in the realm of the family. Polygamy is closely related to marriage because polygamy is a marriage conducted by a husband with more than one wife at the same time. Thus, the case of polygamy is still covered in the realm of marriage guaranteed under the CEDAW. It is also stated in the Universal Declaration of Human Rights by the words "without any limitation due to race, nationality or religion, have the right to marry" and CEDAW with the words "any other field." In addition, the legislation of polygamy, in Indonesia, is set

36 Human Rights Committee, General Comment 18, Nondiscrimination (Thirty-seventh session, 1989), Compilation of General Comments and General Recommendations Adopted by Human Rights Treaty Bodies, U.N. Doc. HRI/GEN/1/Rev.1 at 26 (1994). Available on website: http://www1.umn.edu/humanrts/gencomm/hrcom18.h tm, accessed on $4^{\text {th }}$ August 2014. in the Marriage Law as the specific article of the law.

Based on the five aspects, it can be said that polygamy provision contained in the Marriage Law is discriminatory. The discrimination involves: first, the fulfillment elements of distinction which is an element of discrimination; second, the regulation of polygamy as a direct object; third, polygamy is a partial discrimination of the Marriage Law; fourth, aspect of the recognition where polygamy is allowed under legislation in the form of action and government regulations; the fifth, polygamy is included in the field of marriage where CEDAW and UDHR address equal rights in it.

In the context of state responsibility, human rights violations become an important topic because the state can be positioned as a violator to individuals and a state can be asked the responsibility for it. It means that there must be a mechanism where individuals can complain about the violations of their rights and get the compensation for it. Therefore, CEDAW requires state parties to: first, give recognition to the rights of women; second, provide conditions, both material and spiritual; third, create a mechanism for complaints of violations against women and the provision of compensation. ${ }^{37}$

The third point above, namely the mechanism of complaints of violations against women, is a consequence that should be owned by a state respecting human rights seriously. In Indonesia, until now there is no mechanism for complaints regarding human rights violations committed by the state. Nevertheless, the important thing we need to do and explore in this research is how to define the violations committed by the state, especially with regard to the polygamy in Indonesia.

The concept of state responsibility, at first, appears in the Responsibility of States for Internationally Wrongful Acts. In its provision stipulate that state obligations involve the organs of the state such as legislative, executive and judiciary organs. To gain deep understanding of the state responsibility, the author

37 Hanafi Arief, op.cit., p. 88-97. 
applies the theory of state responsibility by Malcolm N. Shaw. Moreover, according to the theory, in order to determine whether the state has committed human rights violations or not, there must have indicators of state action. Therefore, doctrine of imputability is applied here. According to international law, whoever performs himself with the capacity of a state organ must be regarded to state action. ILC formulation of the doctrine of imputability has a wide scope. Imputability organ or official of the state does not depend on first, institutions of a state whether legislative, executive or judiciary organs; second, the size of an organ or official position of the state; third, the position of the employee, whether central or local employees; fourth, any other status under national law of a state considered as employees or officials. $^{38}$

The problems that will be answered on this sub-topic is what Indonesia may responsible for human rights violations due to its provision and how to define a violation is committed by a state, especially with respect to the setting of polygamy in its legislation. First, the provision of polygamy in Indonesia can make the state responsible for human rights violations due to the occurrence of discrimination against women. In answering this question, the author applies the theory of responsibility by Shaw where there are three conditions to fulfil. The first is the existence of the international legal obligation. International legal obligations arise due to the submission of a country to international convention. When Indonesia must obey the legal obligations of a convention? The answer is when Indonesia has been a party to the convention and has expressed his submission to it by ratification. On the basis of the principle of pacta sunt servanda, Indonesia has a mandate to comply all the provisions of the convention that has been ratified.

CEDAW is an international convention with lots of parties. There are approximately 188 states that have participated in this convention. This convention has the optional proto-

38 Huala Adolf, op.cit., p. 281. col made in New York on October 6, 1999, and entered into force on December 22, 2000. Indonesia has only become a signatory state but Indonesia is not a party to the protocol. However, Indonesia has signed the CEDAW on July 29, 1980 and collected the instruments of ratification on 13 September 1980 by making a reservation on Article 29 Paragraph (1).

In this case, the CEDAW can be categorized as an international convention whose members even more than two parties. Therefore, Indonesia is the party to the convention, Indonesia has international legal obligations to implement the provisions contained in CEDAW. The binding of Indonesia is because Indonesia has ratified CEDAW. This can be compared to the optional protocol to CEDAW which Indonesia only signed but not ratified, then Indonesia is not attached to the optional protocol. Thus, if the question is whether the submission of Indonesia for ratification of CEDAW lead to a legal obligation for Indonesia or not, the answer would be that Indonesia has a legal obligation to comply with CEDAW.

The second is the existence of an act or omission that violates international law obligations is bearing the responsibility of the state. This second requirement contains three important things, namely the existence of an act or omission, violating international law obligations, and bore the responsibility of the state. The act can be classified into two forms of active action (commission) and passive action (omission). Active measures exist as the state to do something. In this case, because the state did not do an active role, the state has violated the rights and freedoms. Silence does not mean no action because silence is a passive action (omission). In this kind of rights should the state do something, or else, the state has violated the rights and freedoms. Indonesian actions taken by the provision of polygamy in the Marriage Law and Government Regulation are active measures.

A next element is an act that imputable to the state responsibility. To answer this question we need imputability principle. Imputability is associated with anyone who acts on behalf 
of what the person is doing the action. In this case imputability to an organ or official of the state does not depend on the institution of the state, whether legislative, executive or judiciary organs. The responsibility of the state will be born when the organs performing actions can be represented by the state. What are the Marriage Law and Regulation (PP) Number 9 Year 1975 on the Implementation of the Law Number 1 Year 1974 on Marriage about?. As we know that the organs that produced both laws are the Parliament and the government, in this case, the president. Therefore, based on the imputability principle, Parliament is the legislative organ of the state because its actions produce an act of state and the president is the executive organ whose actions can generate responsibility of the state.

The third element of the theory of state responsibility belongs to Shaw states that the requirement of responsibility is any damage or loss as a result of an unlawful act. From this element, there are two things that any damage or loss and unlawful acts or omissions. With regard to the existence of an unlawful act or omission, the author has explained clearly in the second element of Shaw's theory about the existence of an act or omission violating international law obligations. Then, the problem is the first element of the existence of damage or loss. Do Marriage Law and the government regulations have caused damage or loss of the rights of women. To determine whether the damage or the loss is quite difficult therefore it requires any proofs that exist in the field through various studies. However, the loss is not always in the form of material, but also immaterial. The existence of discrimination has been proved by the author in the previous sub-topics. As a result of the research, in the fact that the Marriage Law and government regulations have placed men and women unequally, but to decide whether or not that the state has committed a violation, it must be proved by any damage or loss. The damage or loss should have been decided by a court and the decision is exhausted.

\section{Conclusion}

Regulating polygamy only for man and forbid woman to do so tends to threaten Indonesia as a state as a violation of human rights. According to state responsibility theory, state should not discriminate between men and women in all aspects includes marriage. A recognition where polygamy is allowed under legislation is one indicator of inequality between men and women. In addition, Indonesia has international legal obligation to follow international convention which is ratified. International law requires Indonesia to immediately revise the terms of polygamy in the Marriage Law in order to avoid continuous discrimination against women.

In conclusion, unlimited postpone for protecting human rights can be indicated as inability or unwillingness of the state to fulfil and protect women rights. Hence, this conduct can be judged as human rights violation.

\section{References}

Adolf, Huala. 2002. Aspek-Aspek Negara Dalam Hukum Internasional. Jakarta: PT RajaGrafindo Persada;

Alimuddin, 'Undang-Undang Perkawinan, Antara Sejarah Dan Agenda', Harian Kami. Available on website: http://badilag.net/data/ ARTIKEL/UU PERKAWINAN ANTARA SEJA RAH DAN AGENDA.pdf. Accessed December $2^{\text {nd }}, 2014$;

Ansor, Muhammad. "Berbagi Suami Atas Nama Tuhan: Pengalaman Keseharian Perempuan Dipoligami Di Langsa." Ijtihad, Jurnal Wacana Hukum Islam Dan Kemanusiaan. Vol. 14 No. 1. June 2014. Pp. 41-63. DOI: 10.18 326/ijtihad.v14i1.41-63;

Arief, Hanafi. "Legal Protection Against Women Victims by The Indonesian Domestic Violence Act 23, 2004." Sriwijaya Law Review. Vol. 1 No. 1. January 2017. Pp. 88-97. DOI: 10.28946/slrev.Vol1.Iss1.12.pp110-121;

Asplund, Knut D. Et Al., ed. 2008. Hukum Hak Asasi Manusia. Yogyakarta: PUSHAM UII;

Bassiouni, M Cherif. "International Recognition of Victims' Rights." Human Rights Law Review. Vol. 6. No. 2. January 2006. Pp. 203279. DOI: $10.1093 / \mathrm{hrlr} / \mathrm{ngl009}$;

Crawford, James. 2008. Brownlie's Principles of Public International Law. Seventh Edition. 
Oxford: Oxford University Press;

Facio, Alda and Martha I. Morgan. "Equity or Equality for Womern? Understanding CEDAW's Equality Principles." Alabama Law Review. Vol. 60 No. 5. September 2009;

Hannum, Hurst. "Reinvigorating Human Rights for the Twenty-First Century." Human Rights Law Review. Vol. 16 No. 3 September 2016. Pp. 1-43. DOI: 10.1093/hrlr/ ngw015;

Hidayat, Eko. "Perlindungan Hak Asasi Manusia Dalam Negara Hukum Indonesia." JURNAL ASAS. Vol. 8 No. 2. July 2016. Pp. 80-87;

Liunima, Joni Efraim. "Progresive Law Enforcement Towards Human Rights Violation In Kupang City." Jurnal Dinamika Hukum. Vol. 16 No. 1. January 2016. Pp. 79-84. DOI: 10.20884/1.jdh.2016.16.1.462;

Mcgoldrick, Dominic. "The Development and Status of Sexual Orientation Discrimination under International Human Rights Law." Human Rights Law Review. Vol. 16 No. 4. December 2016. Pp 613-668. DOI: 10.1093/ hrlr/ngw030;

Musarrofa, Ita. "Poligami: Antara Legalitas Formal Dan Legalitas Budaya (Studi Kasus Praktik Poligami Kyai Pesantren Di Probolinggo Jawa Timur." Al-Mawarid. Vol. 14 No. 1. 2005. Pp. 198-211;

Mulia, Siti Musdah. 2004. Islam Menggugat Poligami. Jakarta: PT. Gramedia Pustaka Utama;

Mustaqim, Abdul. "Pemikiran Fikih Kontemporer Muhamad Syahrur Tentang Poligami Dan Jilbab." Al-Manahij. Vol. 5 No. 1. January 2011. Pp. 67-80. DOI: $10.24090 / \mathrm{mnh} . v 5 i 1$. 2011.pp67-80;

Mustofa, Ahmad and Khoirul Fata. "Menyoal Kon-tekstualisasi Hukum Islam Tentang Poliga-mi." Jurnal Al-Ulum, Vol. 13 No. 2. Dec-ember 2013. Pp. 415-434;

Nurhidayatuloh. "Dilema Pengujian Undang-Undang Ratifikasi Oleh Mahkamah Konstitusi Dalam Konteks Ketetanegaraan RI." Jurnal Konstitusi. Vol. 9. No. 1 March 2012. Pp. 113-134;

---. 2008. Pertimbangan Hakim Dalam Kasus Poligami (Studi Putusan Pengadilan Agama DIY Tentang Poligami Tahun 2006). Yogyakarta: Sunan Kalijaga State Islamic University;

Philip, Christanugra. “Tanggung Jawab Negara
Terhadap Perlindungan Hak Asasi Manusia Menurut Hukum Internasional." Lex Administratum. Vol. 4. No. 2. February 2016. Pp. 33-39;

Sanyoto, "Implementasi Poligami Antinomi Antara Individual Rights Dan Social Rights," Jurnal Dinamika Hukum. Vol. 8 No. 1 January. 2008. Pp. 51-55. DOI: 10.20884/1.jdh. 2008.8.1.31;

Shaw, Malcolm N. 2008. International Law, 6th edition. Cambridge: Cambridge University Press.

Sutandi, Wilda Triana. "Gambaran Simtom Depresi Pada Istri Yang Dipoligami." Neotic Psychology. Vol. 1 No. 2. January 2011. Pp. 102-109;

Verma, Justice J.S. "Human Rights Redefined: The New Universe of Human Rights." Journal of the NHRC. Vol. 1 2002. Pp. 117;

Warits, Abd. and Abd. Wahed. "Praktik Poligami Di Bawah Tangan Di Desa Laden Kabupaten Pamekasan." AL-Ahkam. Vol. 9 No. 2. December 2014. Pp. 223-259.

Wartini, Atik. "Poligami: Dari Fiqh Hingga Perundang-Undangan." Hunafa: Jurnal Studia Islamika. Vol. 10 No. 2 December 2013. Pp. 237-268. DOI: 10.24239/jsi.v10i2.29. 237-268;

Wulandari, Cahya and Indung Wijayanto. "Gender-Based Restorative Justice for Victims of Violence Against Women." Jurnal Dinamika Hukum. Vol. 15 No. 1. January 2015. Pp. 82-88. DOI: 10.20884/1.jdh.2015.15. 1.368. 